
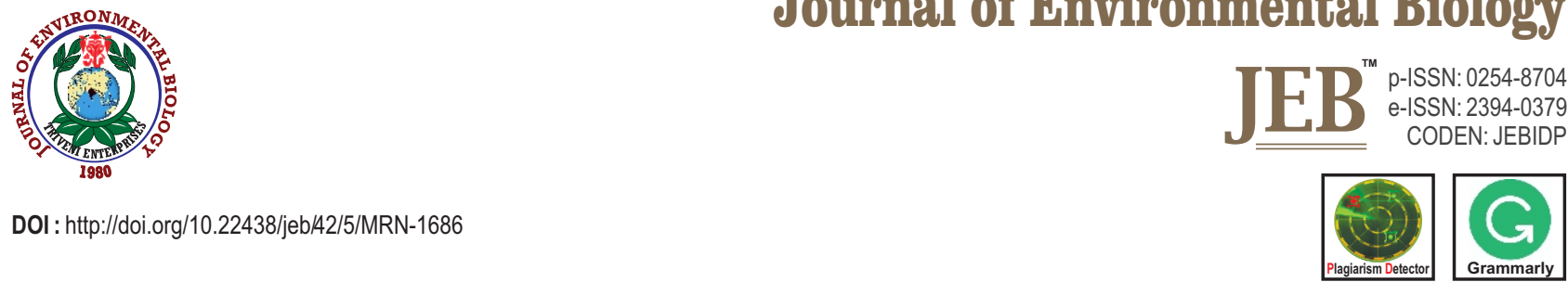

\title{
Evaluation of different lignocellulosic substrates for cultivation of medicinal mushroom Ganoderma lucidum
}

\author{
G. Thiribhuvanamala* and A.S. Krishnamoorthy \\ Department of Plant Pathology, Tamil Nadu Agricultural University, Coimbatore-641 003, India \\ *Corresponding Author Email : ragumala2000@gmail.com
}

Received: 02.09.2020

Revised: 16.02 .2021

Accepted: 04.05.2021

\section{Abstract}

Aim: The present study was formulated with an aim to evaluate different locally available residues from trees such as mixed saw dust, saw dust of coconut wood log, coconut leaf stalks/petiole, coconut coir waste, saw dust of areca nut wood log for cultivation of medicinal mushroom Ganoderma lucidum.

Methodology: Locally available agro residues viz., mixed saw dust, saw dust of coconut wood log, chopped coconut leaf stalks/petiole, coconut coir waste, saw dust of areca nut wood log were mixed with $20 \%$ wheat bran as supplement and packed in bags at $175 \mathrm{~g} / \mathrm{bag}$, autoclaved and aseptically inoculated with grain spawn of $G$. lucidum and provided with different temperature and humidity conditions for production of fruiting bodies.

Results: Among the substrates, coconut wood log saw dust supported early spawn run within 46.5 days and early pinhead production on day 54 followed by pinhead expansion in 62.3 days and first harvest within 70.5 days. The average number of fruiting bodies were also higher (5.75 numbers/bag) with an average weight of 13.5 $\mathrm{g} /$ fruiting body that gave significantly higher yield of 77.5 $\mathrm{g} / 175 \mathrm{~g}$ substrate with bioefficiency of $44.3 \%$ in a cropping cycle of 100.5 days compared to other substrates.

Interpretation: The results show that coconut wood log saw dust substrate offers great scope for artificial cultivation of $\mathrm{G}$. Iucidum with a significant bioefficiency of $44.3 \%$.

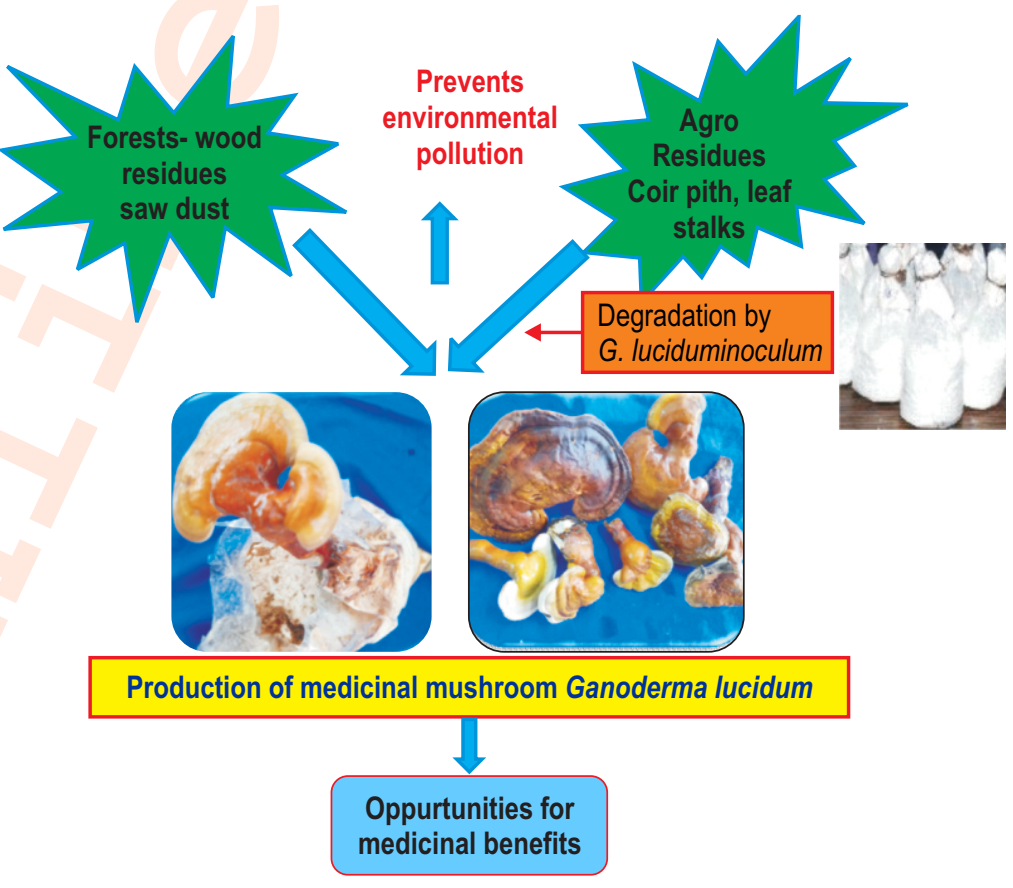

Key words: Bioefficiency, Ganoderma lucidum, Saw dust, Yield

How to cite : Thiribhuvanamala, G. and A.S. Krishnamoorthy: Evaluation of different lignocellulosic substrates for cultivation of medicinal mushroom Ganoderma lucidum. J. Environ. Biol., 42, 1314-1319 (2021). 


\section{Introduction}

Ganoderma lucidum (Fr.) Karst, with its bracket-shaped fruiting body called 'Reishi' in Japanese and 'Lingzhi' in Chinese, is a species of basidiomycetes which belongs to family Polyporaceae (or Ganodermaceae), order Aphyllophorales (Yang and Liau, 1998; Wagner et al., 2003). In traditional Chinese medicine, Ganoderma lucidum occupies an important place and is also known as the 'elixir of life' and the 'mushroom of immortality' (Fang and Zhong, 2002). G. lucidum also contains 400 bioactive compounds with copious levels of triterpenes and polysaccharides that are known to possess antitumour, antiinflammatory, antioxidant hepato-protective, antimicrobial, hypotensive, antidiabetic and acetylcholinesterase inhibitory activities (Cao et al., 2012; Darija Cor et al., 2018). The medicinal attributes of G.lucidum has been used for centuries and led to the fast growth of mushroom nutraceuticals in the market. Currently, lot of awareness about Ganoderma has been developed which has led to large-scale cultivation artificial cultivation and isolation of bioactive components. Cultivation of this medicinal mushroom has been attempted by many researchers worldwide; however, the bioefficiency varies with different substrates and supplementations. Globally, there are numerous commercial products available in the form of powders, dietary supplements, capsules, liquid drops and tea prepared from mycelia, spores and fruit body of $G$. lucidum.

Reports show that Ganoderma species cause white rot of hard woods by decomposing lignin, cellulose and related polysaccharides (Adaskaveg et al., 1991). Ganoderma species has a wide host range, with more than 44 species from 34 genera of plants being identified as potential hosts (Venkatarayan, 1936); however, G. lucidum is capable of thriving in the subtropical and temperate climate zones, in the forests of Asia, Europe and North and South America as a saprophyte or facultative parasite. Owing to high medicinal value and its adaptability to various hosts and temperature ranges, there is growing interest among scientists, especially in the tropical Asian countries, for artificial cultivation to meet the growing demand of G. lucidum. Earlier wood log cultivation of G. lucidum was practiced but it involved longer duration cropping cycle; later artificial cultivation using lignocellulosic substrates were attempted in substrates containing approximately $60-70 \%$ lignocellulose by dry weight (Cosgrove , 1997) where lignocellulosic component of the substrate is degraded and transformed into fungal biomass (Shoham et al., 1999; Martinez et al., 2010) and accounts for 85\% of fruiting body and $45 \%$ of mycelial dry weight by using different substrates such as grain saw dust, broadleaf hardwood trees (commonly used species include oak, pecan, elder, choke, cherry and plum), wood logs, tree stumps, agro residues and sawdust bags (Chen et al., 1999; Boh et al., 2007). Reports show that $G$. lucidum has been cultivated in sawdust from Acacia sp., Alnus sp., Carpinus sp., Dalbergia sp., Dipterocarpus sp., Fagus sp.,
Pinus sp., Populus sp., Quercus sp. and Swietenia sp. (Erkel, 2009; Roy et al., 2015). However, the yield varied which may be due to secretion pattern of lignocelluloytic enzymes in different substrates. Wood logs and branches of felled trees left as residues in the field and forest take long time to degrade. Naturally, hence, the present study aimed at evaluating different locally available coconut based substrates in comparison with mixed saw dust substrate for production of G. Iucidum. Certainly, the results emanating will provide an insight on developing low cost production technology for cultivation high medicinal valued G.lucidum fruiting bodies by farmers and industrialists for large scale production.

\section{Materials and Methods}

Testing different wood based substrates for sporophore production and yield of $\mathrm{G}$. Iucidum : The culture of $\mathrm{G}$. lucidum (NCBI accession no. JN692272) was obtained from the Department of Plant Pathology, Tamil Nadu Agricultural University, Coimbatore. Spawn of G. Iucidum was prepared in sorghum grain as substrate. Fully grown 15-day-old G.lucidum spawn was used for the studies. The cultivation technology provided by the Directorate of Mushroom Research, Solan, Himachal Pradesh (Rai and Tewari, 2010) was adopted in this study.

For cultivation of G. lucidum, different coconut wood based residues, viz., saw dust of coconut wood log, coconut leaf stalks/petiole, coconut coir waste, saw dust of areca nut wood log and mixed saw dust were mixed separately with $20 \%$ wheat bran as supplement. Calcium sulphate (gypsum) and calcium carbonate (chalk powder) @2\% were added to get a pH of 5.5 and then the entire contents were made up to $65 \%$ moisture content. Polypropylene bags were filled with the respective saw dust substrates @ $175 \mathrm{~g}$ per bag and autoclaved at 15 lbs for 2 hrs. Next day, upon cooling, the bags were inoculated aseptically with $3 \%$ sorghum grain spawn inoculum of G. lucidum and incubated in dark at room temperature $\left(27-28^{\circ} \mathrm{C}\right)$ until complete spawn run. The experiment was replicated four times in a randomised block design. After completing the spawn run, the bags were observed for primordial initiation and then maintained at $80 \%$ relative humidity and $28^{\circ} \mathrm{C}$ in cropping rooms for pinheads to appear. Pinheads later grew longer with yellow stipe bearing white colour at the tip. The temperature was lowered again to $25^{\circ} \mathrm{C}$ with relative humidity of $60-65 \%$ for thickening of cap margins. After harvesting of the first flush, the mushrooms bags were kept in cropping rooms as mentioned earlier for inducing second flush. Likewise, two harvests were reaped and total yield was calculated. The data on days to spawn run (DFSR), days to pinhead formation (DFPF), days for pinhead expansion (DFPE), days for first harvest (DFFH), average number of fruiting bodies per bag, average weight of single sporophore/fruiting body (g), average yield per bag of $175 \mathrm{~g}$ substrate were recorded. Total cropping cycle (TCP) was recorded. The biological efficiency was 
calculated in terms of percentage.

\section{Results and Discussion}

The perusal of data (Table 1) showed that all the substrates supplemented with wheat bran viz., mixed saw dust, saw dust of coconut wood log, coconut leaf stalks/petiole, coconut coir waste, saw dust of areca nut wood log supported the growth of mycelium and produced fruiting bodies with a cropping cycle ranging from 100 to 143.5 days. Among the substrates, coconut wood log substrate recorded early spawn run completion in 46.5 days and pinhead emergence in 54 days and pinhead expansion within 62.3 days compared to other substrates (Fig.1). The next best treatments, chopped coconut leaf stalk and arecanut wood log substrate were almost on par and supported early completion of spawn run (52.7 and 51.5 days), pinhead formation (57 and 59 days) pinhead expansion (67.3and 69.5 days) when compared with mixed saw dust and coir pith waste substrates. In mixed saw dust and coconut coir pith substrate, the spawn running was slow and took 58 and 80 days to cover the substrates, which delayed pinhead emergence (70.5 and 95 days) and pinhead expansion (81 and 103.5 days) .

However, the average number of fruiting bodies were on par in coconut wood log saw dust, areca nut wood log saw dust substrate and coconut leaf stalk (chopped) substrate with 5.7, 5.5 and 5.5 numbers per bag, respectively, followed by mixed saw dust (4.75 numbers) which may be due to variation in nutrients of the substrate. However, no significant difference in the average weight of fruit body was noticed, which ranged from 11.75 to 13.5 in all the substrates tested. The single fruiting body weight in coconut saw dust recorded $13.5 \mathrm{~g}$. The maximum yield of $77.5 \mathrm{~g}$ $175 \mathrm{~g}^{-1}$ substrate per bag was recorded in coconut wood log saw dust with bioefficiency of $44.3 \%$ in a total cropping cycle of 100.5 days. G. lucidum, mostly observed as a facultative saprophyte in weakened coconut trees and in felled coconut tree stumps, prefers lignocellulosic substrates of coconut wood log and this could be the reason for quick colonisation and maximum yield. The areca nut wood log saw dust substrate, coconut leaf stalk (chopped) substrate and mixed saw dust substrate recorded $68.75,69.5$ and $63.75 \mathrm{~g}$ per bag of $175 \mathrm{~g}$ substrate with bioefficiency of $39.7,39.3$ and $36.4 \%$ respectively. Though coconut coir pith supported fairly good growth, yield was comparatively lower ( $25.6 \%$ bioefficiency) compared to other substrates. The reduction of yield in coir pith waste could be explained by delayed pinhead formation that may have exhausted nutrients.

Earlier natural log cultivation was practical to cultivate Ganoderma but the yield was lower with longer cropping period, nearly 6-24 months to produce fruiting bodies compared to sawdust synthetic log cultivation (Chen, 2002; Pegler, 2002). Perusal of literature showed that sawdust of various tree species, viz. Albizia procera, Albizia richardiana, Alnus nepalensis, Bombax ceiba, Borassus flabellifer, Dalbergia sissoo, Eucalyptus camaldulensis, Mangifera indica, Shorea robusta and their mixed sawdust (Gurung et al., 2012) alone and in combination with rice bran, wheat bran and finger millet or ragi (Eleusine coracana) powder for the purpose of cultivation of $G$. lucidum were also evaluated (Veena et al., 2006, 2011). Reports show that supplementation of rice husk, coconut fibre, peanut hulls, corn, sorghum, sugarcane bagasse, sucrose, wheat and rice bran to the substrates enhanced yield (Triratana et al., 1991). The yield was increased significantly when $1 \%$ molasses and gluten meal were added to sawdust and bran based medium (Erkel, 2002). Gonzalez-Matute et al. (2002) reported that sunflower seed hull at $5 \%$ served as the main energy and nutritional source that significantly improved productivity of $G$. lucidum. Even tea waste (Peksen and Yakupogl,2008) and coffee pulp supplemented with wheat bran, bean pod and maize stem used as substrate supported G. lucidum biological efficiencies ranging from 6.9 to $8.2 \%$ (Gonzalez -Bernabe et al., 2015). Substitution of poplar sawdust with $5 \%$ malt extract and $10 \%$ wheat bran resulted in yield $142.44 \mathrm{~g} \mathrm{~kg}^{-1}$ and biological efficiency of $18.68 \%$ (Majid, 2012) and mixture of saw dust of rubber and mango (50:50) or rubber and Lunumidella (50:50) (Jeewanthi et al., 2017) were successfully used for cultivation of G. lucidum. as

Table 1: Values of different yield parameters of Ganoderma lucidum due to supplementation of lignocellulosic substrates.

\begin{tabular}{llllllllll}
\hline Substrates & DFSR & DFPF & DFPE & DFFH & $\begin{array}{l}\text { Av. no. fruiting } \\
\text { bodies/bag(n) }\end{array}$ & $\begin{array}{l}\text { Av. wt. of fruiting } \\
\text { body }(\mathbf{g})\end{array}$ & $\begin{array}{l}\text { Av. yield } \\
\text { (g)/bag }\end{array}$ & $\begin{array}{l}\text { TCP } \\
\text { (days) }\end{array}$ & $\begin{array}{l}\text { BE } \\
(\%)\end{array}$ \\
\hline Mixed saw dust & 58.0 & 70.5 & 81.0 & 92.25 & 4.75 & 13.25 & 63.75 & 122.5 & 36.4 \\
Coconut wood log saw dust & 46.5 & 54.0 & 62.3 & 70.5 & 5.75 & 13.50 & 77.50 & 100.5 & 44.3 \\
Coconut leaf stalk (chopped) & 52.75 & 57.0 & 67.3 & 73.5 & 5.50 & 13.50 & 68.75 & 103.5 & 39.3 \\
Areca nut wood log saw dust & 51.5 & 59.0 & 69.5 & 77.7 & 5.50 & 12.75 & 69.50 & 107.75 & 39.7 \\
Coir pith waste & 80.0 & 95.0 & 103.5 & 115.5 & 3.75 & 11.75 & 44.75 & 145.5 & 25.6 \\
CD (P=0.05) & 4.92 & 2.59 & 3.91 & 7.8 & 1.13 & 1.95 & 17.87 & 7.9 & \\
SEd & 2.26 & 1.19 & 1.79 & 3.7 & 0.52 & 0.89 & 8.20 & 3.7 \\
\hline
\end{tabular}

BE : Biological efficiency; DFFH: Days for first harvest; DFPE: Days for pinhead expansion; DFPF: Days to pinhead formation; DFSR : Days to spawn run; TCP: Total cropping period 


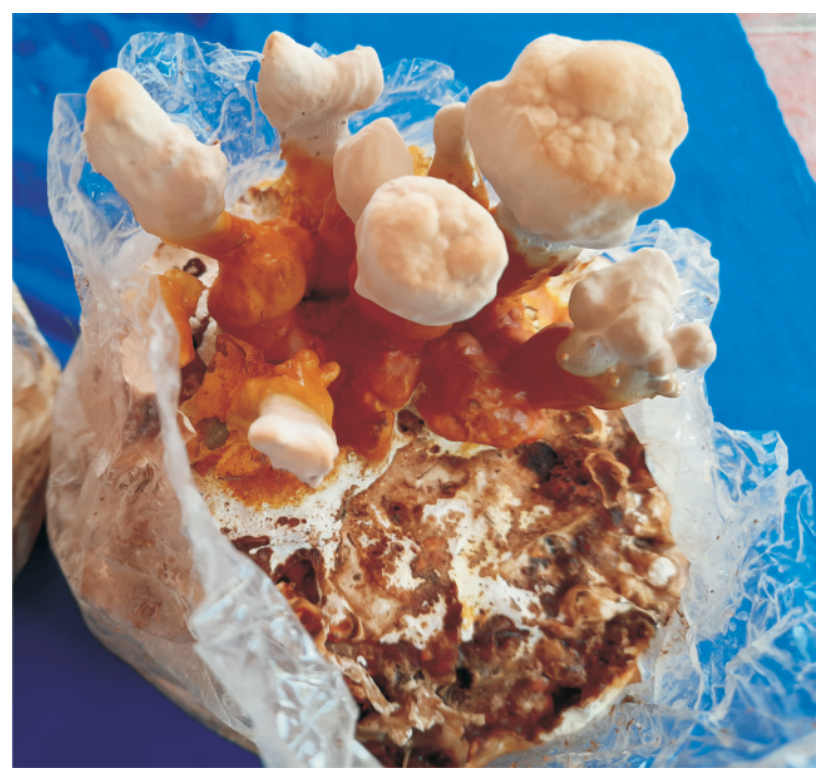

(a)

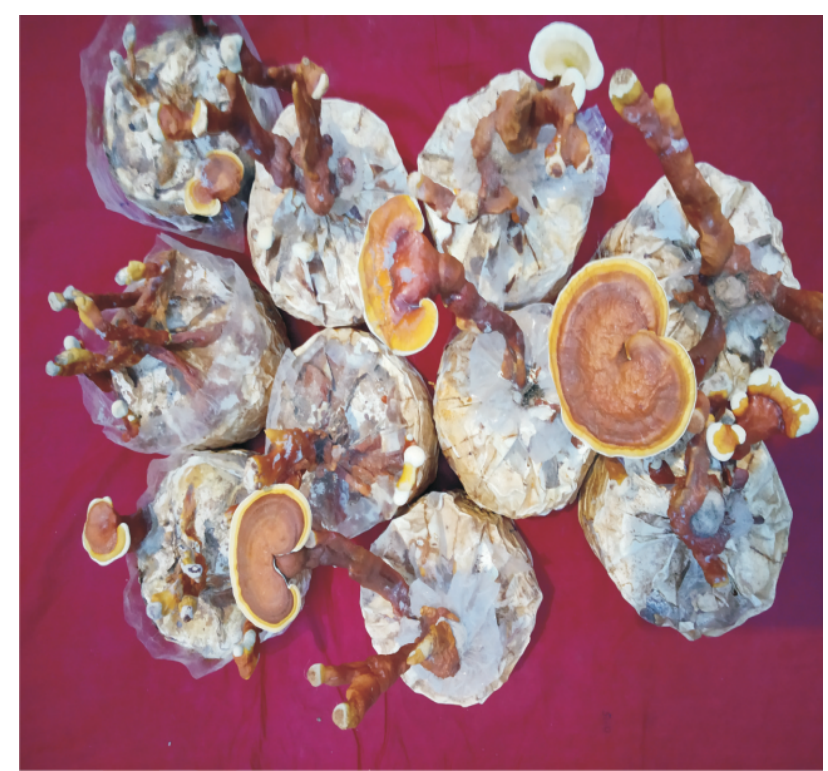

(b)

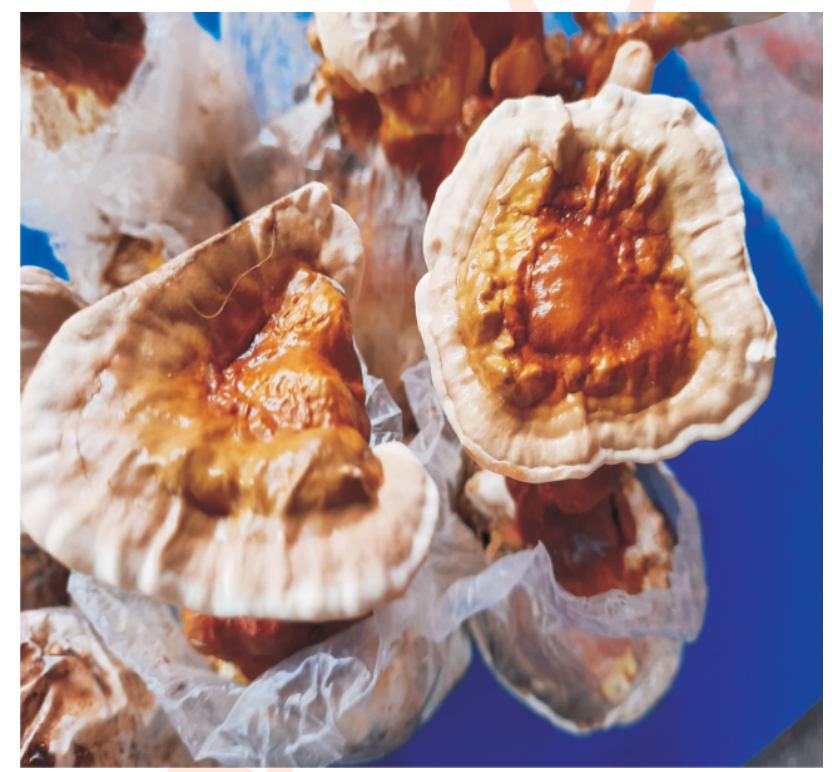

(c)

Fig. 1 : Production of Ganoderma lucidum in coconut saw dust substrate supplemented with wheat bran: (a) Primordial initiation; (b) Fruiting body production and (c) Matured sporophores.

in the present study. In accordance with this study, Roy et al. (2015) reported that Swietenia mahagoni saw dust supplemented with wheat bran provided uniform mycelial growth and primordial formation and days for harvesting on day 60 with $235.2 \mathrm{~g} \mathrm{~kg}^{-1}$ yield and biological efficiency of $7.6 \%$. In the present study, though $\mathrm{G}$. lucidum showed luxuriant mycelial colonisation on any lignocellulosic waste, only coconut wood log saw dust supported significant production of fruiting bodies with appreciable bioefficiency, which may be due to presence of specific nutrients and lignocellulose.
It can be inferred that in addition to cellulose and hemicelluloses, wheat bran contains phenolic acids that could induce more ligninolytic enzymes such as lignin peroxidase, laccase from the mycelium of $G$. lucidum in coconut saw dust substrate which degraded the substrate quickly and supported maximum fruiting bodies in a short cropping cycle and led to high yield in this study. Moreover it is understood that though G.lucidum is seen as parasite in weak coconut trees (Kandan et al., 2010), once the fungus enter coconut trees it produces bracket shaped fruiting bodies only after several years; but it does 
not affect healthy trees. But when it is artificially cultivated in coconut saw dust substituted with $20 \%$ wheat bran , the fungus colonises the coconut saw dust substrate and produces fruiting bodies within 70.5 days and this explains the preference of this fungus for coconut saw dust substrate. Similarly, Escribano (2020) also reported that G.lucidum cultivated in Populus tremula wood residues subjected to cold shock treatment at $5^{\circ} \mathrm{C}$ induced more primordia formation leading to enhanced yield and $\beta$ glucan in fruit bodies. Zarzoliana Ralte et al.(2020) reported that local mixed saw dust (LMS) +wheat bran (80:20) showed a highest yield with bioefficiency of $54.5 \%$; however LMS + wheat bran $(90: 10)$ took reduced days for fruit body maturation. Similarly, Koutrotsios et al.(2019) found that fruiting bodies of G. lucidum produced from Olive leaf pruned residues exhibited up to a threefold increase in $\beta$-glucan a polysaccharide used in medical industry. They further explained that the cultivation in substrates rich in phenolic and antioxidant compounds may play role in significant increase in the respective components in fruit-bodies. Perusal of literature shows multifaceted actions of primary metabolites of Ganoderma such as polysaccharides, proteins and triterpenes (De Silva et al., 2012; Hapuarachchi et al., 2016; Bhat et al., 2021) that finds application in medicine. Hence, this study offers great scope for safe and ecofriendly management of coconut residues for production of G.lucidum, which is highly priced for its medicinal value. However, safe disposal of spent substrate is recommended.

Coconut wood log saw dust proved to be the best substrate in terms of superior bioefficiency. Similarly, areca nut wood log saw dust and coconut leaf stalk (chopped) could be used as alternate substrates which means that recycling of such agro residues for the commercial production of medicinal mushroom G. Iucidum can replace chemical drugs in future.

\section{Acknowledgment}

The authors thank the ICAR-All India Coordinated Mushroom Improvement Project, Directorate of Mushroom Research, Solan, for funding this study.

\section{Add on information}

Authors' contribution : Dr. G. Thiribhuvanamala formulated and executed the research work, analysis and manuscript preparation Dr.A.S. Krishnamoorthy : provided overall guidance

Research content: The research content is original has not been published else where

\section{Ethical approval : Notapplicable}

Conflict of interest :The author declares that there is no conflict of interest

Data from other sources: Notapplicable
Consent to publish : All the authors agree to publish the paper in Journal of Environmental Biology.

\section{References}

Adaskaveg, J.E., R.A. Blanchette and R.L. Gilbertson: Decay of date palm wood by white-rot and brown-rot fungi. Cana. J. Bot., 69, 615-629 (1991).

Bhat, Z.A., A.H. Wani, J.M. War and M.Y Bhat: Major bioactive properties of Ganoderma polysaccharides: A review. Asian J. Pharm. Clin. Res.,14,11-24 (2021).

Boh, B., M. Berovic, J. Zhang and L. Zhi-Bin: Ganoderma lucidum and its pharmaceutically active compounds. Biotechnol. Ann. Rev., 13, 265-301 (2007).

Cao, Y., S.H. Wu and Y.C. Dai. Species clarification of the prize medicinal Ganoderma mushroom "Lingzhi" Fungal Diversity, 56, 49-62 (2012)..

Chen, A.W.: Cultivation of the medicinal mushroom Ganoderma lucidum (Curt. Fr.) P Karst. (Reishi) in North America. Int. J. Med Mushrooms,1,263-82(1999).

Chen A.W.: Natural log cultivation of the medicinal mushroom, Ganoderma lucidum (Reishi). Mushroom Growers's Newsletter, 3, 2-6 (2002).

Cosgrove D.J.: Assembly and enlargement of the primary cell wall in plants. Annu. Rev. Cell Dev. Biol.,13, 171-201 (1997).

Darija, C., Z. Knez and M.K. Hrmcc: Antitumour, antimicrobial, antioxidantand anti acetylcholinesterase effect of Ganoderma lucidum terpenoids and polysaccharides: A review. Molecules, 23, 64 (2018).

De Silva D.D., S. Rapior, F. Fons., A.H. Bahkali and K.D. Hyde: Medicinal mushrooms in supportive cancer therapies: An approach to anti-cancer effects and putative mechanisms of action. Fungal Diversity, 55, 1-35 (2012).

Escribano, M.C., J.M Pihlava, J.Miina, P.Veteli, R. Linnakoski and H. Vanhanen: Effect of strain, wood substrate and cold treatment on the yield and $\beta$-Glucan content of Ganoderma lucidum fruiting Bodies. Molecules, 25, 4732 (2020).

Erkel, E.I.: Yield performance of Ganoderma lucidum (Fr.) Karst cultivation on substrates containing different protein and carbohydrate sources. Afr. J. Agricu. Res., 4, 1331-1333 (2002)

Erkel, E.I.: The effect of different substrate mediums on yield of Ganoderma lucidum (Fr.) Karst. J. Food Agric. Environ., 7, 841844 (2009).

Fang, Q.H. and J.J. Zhong: Effect of initial pH on production of ganoderic acid and polysaccharide by submerged fermentation of Ganoderma lucidum. Process. Biochem., 37, 769-774 (2002).

Gonzalez-Matute, R., D. Figlas., R. Devalis., S. Delmastro and V. Curvetto: Sunflower seedhulls as a main nutrient source for cultivating Ganoderma lucidum. Micol. Aplicada Int., 14, 19-24 (2002).

Gonzalez-Bernabe, T.M., G.Cayetano-Catarino, A.Bernabe-Villanueva, M.D.R. Flores, A. Rios and J.P. Salgado: Cultivation of Ganoderma lucidum on agricultural by products in Mexico. Micologia Aplicada Int., 27, 25-30 (2015).

Gurung, O.K., U. Budathoki and G. Parajuli: Effect of different substrates on the production of Ganoderma lucidum (Curt.:Fr.) Karst. Our Nature, 10, 191-198 (2012).

Hapuarachchi KK., T.C. Wen, C.Y. Deng, J.C. Kang and K.D. Hyde: Mycosphere Essays 1: Taxonomic confusion in the Ganoderma 
lucidum species complex. Mycosphere, 6, 542-559 (2015).

Jeewanthi, L.A.M.L., K. Ratnayake and P. Rajapakse: Growth and yield of Reishi mushroom (Ganoderma lucidum (Curtis) P. Karst] in different sawdust substrates. J. Food Agric., 10, 8-16 (2017).

Kandan, A., Bhaskaran, R. and R. Samiyappan: Ganoderma - a basal stem rot disease of coconut palm in south Asia and Asia pacific regions. Arch. Phytopathol. Plant Protec., 43, 1445-1449 (2010).

Koutrotsios,G.,M.Patsou,E.K. Mitsou, G.Bekiaris,M.Kotsou, P.A Tarantilis,V.Pletsa, A.Kyriacou and Zervakis, G.I.: Valorization of olive by-products as substrates for the cultivation of Ganoderma lucidum and Pleurotus ostreatus mushrooms with enhanced functional and prebiotic properties. Catalysts, 9, 537 (2019).

Majid, A., M. Tavana, M. Farsi and F. Oroojalian: Yield performance of Lingzhi or Reishi medicinal mushroom, Ganoderma lucidum (W. Curt.: Fr.) P. Karst (Higher Basidiomycetes), using different waste materials as substrates. Int. J. Medi. Mushr., 14, 521-527 (2012).

Martínez, A.T., M. Speranza, F.J. Ruiz-Duenas, P. Ferreir, S. Camarero and F. Guillen: Biodegradation of lignocellulosics: Microbial, chemical and enzymatic aspects of the fungal attack of lignin. Int. Microbiol., 8,195-204. (2010).

Pegler, D.N.: Useful fungi of the world: The Ling-zhi - the mushroom of immortality. Mycologist, 16, 100-101(2002).

Peksen, A. and G. Yakupoglu: Tea waste as a supplement for the cultivation of Ganoderma lucidum. World J. Microbiol. Biotechnol., 25, 611-618 (2008).

Rai, R.D. and P.P. Tewari: Cultivation technology of Ganoderma lucidum, Publishers: National Research Centre for Mushroom Chambaghat, Solan (2010)

Roy, S., M.A.A. Jahan., K.K. Das, S.K. Munshi and R. Noor: Artificial Cultivation of Ganoderma lucidum (Reishi Medicinal Mushroom) using different saw dust as substrates. Am. J. Biosci., 3, 178 (2015).

Shoham, Y., R. Lamed and E.A. Bayer: The cellulosome concept as an efficient microbial strategy for the degradation of insoluble polysaccharides. Trends Microbiol., 7, 275-81 (1999).

Subarna, R., M.A.A. Jahan, K.K. Das, S.K. Munshi and R. Nool: Artificial Cultivation of Ganoderma lucidum (Reishi Medicinal Mushroom) using different sawdusts as substrates. Amer. J. BioSci., 3, 178$182(2015)$

Triratana, S., S. Thaithatgoon and M. Gawgla: Cultivation of Ganoderma lucidum in sawdust bags. Int. Soc. Mush. Sci.,13, 567-572 (1991).

Veena, S.S and M. Pandey: Evaluation of the locally available substrate for the cultivation of Indigenous Ganoderma lucidum isolate. J. Mycol. PI. Pathol., 36, 434-438 (2006)

Veena, S.S. and M. Pandey: Paddy straw as a substrate for the cultivation of Lingzhi or Reishi medicinal mushroom, Ganoderma lucidum (W. Curt.: Fr.) P. Karst. in India. Int J. Med. Mushr., 13, 397400 (2011).

Venkatarayan, S.V.: The biology of Ganoderma lucidum on areca and coconut palms. Phytopathology, 26, 153-175(1936).

Wagner, R., D.A. Mitchell, G.L. Sassaki, M.A. Amazonas and M.Berovic. Current techniques for the cultivation of Ganoderma lucidum for the production of biomass, ganoderic acid and polysaccharides. Food. Technol. Biotechnol., 41, 371-382 (2003)

Yang, F.C. and C.B. Liau: Effect of cultivating conditions on the mycelial growth of Ganoderma lucidum in submerged flask cultures. Bioprocess. Eng., 19, 233-236 (1998).

Zarzoliana R., A. A. Lal and S. Simon: Evaluation of the locally available substrates for the cultivation of Ganoderma lucidum (W.Curt.:Fr.) Karst (Reishi Mushroom) in Prayagraj, U.P. Int. J. Curr. Microbiol. App. Sci., 9, 1564-1569 (2020). 